\title{
DISTRIBUSI BAHAN KERING SORGUM (Shorgum bicolor (L.) Moench) YANG DITUMPANGSARIKAN DENGAN UBIKAYU (Manihot esculenta Crantz.)
}

\author{
Reni Yuliasari, Muhammad Kamal \& Sunyoto \\ Jurusan Agroteknologi, Fakultas Pertanian Universitas Lampung \\ Jl. Prof. Soemantri Brodjonegoro, No. 1, Bandar Lampung 35145 \\ E-mail: reniyuliasari@rocketmail.com
}

\begin{abstract}
ABSTRAK
Distribusi bahan kering memiliki peranan penting dalam proses pembentukan hasil tanaman sorgum. Faktor genetik dan lingkungan berpengaruh pada proses akumulasi bahan kering, pemahaman yang lebih baik terhadap distribusi bahan kering pada pola pertanaman berbeda sangat penting. Penelitian ini dilakukan dengan tujuan berikut mengetahui pengaruh pola pertanaman distribusi bahan kering sorgum dan mengetahui pengaruh distribusi bahan kering beberapa genotipe sorgum dalam sistem tumpangsari. Penelitian dilaksanakan di Kebun teknis Badan Pengkajian Teknik Pertanian (BPTP) Lampung selatan, Laboratorium Benih Fakultas Pertanian, Universitas Lampung dari bulan November 2012 sampai bulan Maret 2013. Rancangan perlakuan disusun dengan faktorial dalam rancangan petak terbagi kelompok teracak sempurna (RKTS) dengan tiga kali ulangan. Petak utama adalah pertanaman tumpangsari dan monokultur sedangkan anak petak adalah genotipe tanaman sorgum Batan S-3, Batan S-12, Keller, Wray, Numbu. Petak percobaan yang digunakan pada penelitian ini berukuran 4 x 3,2 m. Data dianalisis dengan sidik ragam dan perbedaan nilai tengah perlakuan ditentukan dengan uji BNJ pada taraf 5\%. Hasil penelitian menunjukkan bahwa pola pertanaman monokultur dan tumpangsari berpengaruh pada bobot kering daun 6 12 mst, batang 6 dan 10 mst , akar 4-12 mst. Pertanaman monokultur menghasilkan bobot kering daun, batang, dan akar lebih besar daripada pertanaman tumpangsari. Sebagian besar bahan kering diakumulasikan pada batang diikuti daun dan yang terkecil pada akar. Perbedaan genotipe berpengaruh terhadap bobot kering daun pada $6-12$ mst batang pada 4, 6 dan 10 mst dan akar pada 6 dan 8 mst.
\end{abstract}

Kata Kunci : Biomasa, Sorgum,Tumpangsari.

\section{PENDAHULUAN}

Sorgum (Sorghum bicolor [L.] Moench) adalah tanaman serealia yang potensial untuk dibudidayakan dan dikembangkan, khususnya pada daerah-daerah marginal dan kering di Indonesia. Keunggulan sorgum terletak pada daya adaptasi agroekologi yang luas, tahan terhadap kekeringan, produksi tinggi, perlu input lebih sedikit serta lebih tahan terhadap hama dan penyakit dibanding tanaman pangan lain. Selain itu, tanaman sorgum memiliki kandungan nutrisi yang tinggi, sehingga sangat baik digunakan sebagai sumber bahan pangan maupun pakan ternak alternatif (Sirappa, 2003).

Tumpangsari singkong dengan sorgum merupakan dua jenis tanaman yang sesuai untuk ditumpangsarikan asalkan kedua tanaman ditanam dengan waktu yang bersamaan, karena singkong dan sorgum merupakan tanaman yang mempunyai habitus yang berbeda, sehingga dalam memanfaatkan pengaruh dari faktor lingkungan akan berbeda pula sehingga tidak akan berpengaruh terhadap proses fotosintesis, biomasa tanaman, partisi tanaman. Biomasa tanaman merupakan suatu ukuran komphrehensif pertumbuhan tanaman.
Laju penggunaan fotosintat dalam tanaman dapat mempengaruhi tingkat fotosintesis; laju fotosintesis menurun apabila fotosintat terakumulasi tanaman (Sitompul dan Guritno, 1995). Oleh karena itu proses translokasi dan laju pemanfaatan fotosintat sangat penting, sehingga pendistribusian hasil fotosintat ke organ lain seperti batang, daun, dan akar sangat kritikal. Distribusi bahan kering merupakan pembagian hasil fotosintesis yang dikolerasikan pada organ-organ tanaman baik dalam bentuk struktur vegetatif maupun generatif (Gardner et al.1991). Distribusi bahan kering dipengaruhui oleh faktor genetik dan lingkungan (Zanski dan Shaffer, 1996). Pengetahuan ini sangat penting tidak hanya untuk memperluas wawasan akan proses pertumbuhan tanaman khususnya pembentukan biomasa, tetapi juga untuk menilai efisiensi pertumbuhan tanaman dalam penggunaan bahan pertumbuhan (substrat).

\section{BAHAN DAN METODE}

Penelitian ini dilaksanakan di kebun teknis Badan Pengkajian Teknik Pangan Pertanian (BPTP) Desa 
Negara Ratu Kecamatan Natar, Kabupaten Lampung Selatan dan Laboratorium Benih Fakultas Pertanian Universitas Lampung pada bulan November 2012 sampai Maret 2013. Bahan yang digunakan adalah bibit ubikayu: Kasetsart; dan 5 genotipe sorgum yaitu Batan S-3, Batan S-12, Keller, Wray, Numbu. Pupuk Urea, SP-36, KCl. Sedangkan alat-alat yang digunakan adalah bajak garu dan bajak rotari, alat tugal,cangkul, sabit, pisau, bambu, meteran, kertas koran, kertas label, oven, timbangan elektrik, streples, tali raffia, plastik, karung, buku tulis, spidol, camera digital, pena, golok.

Rancangan perlakuan disusun dengan faktorial dalam rancangan petak terbagi kelompok teracak sempurna (RKTS) dengan tiga kali ulangan. Petak utama adalah pertanaman tumpangsari dan monokultur sedangkan anak petak adalah genotipe tanaman sorgum Batan S-3, Batan S-12, Keller, Wray, Numbu. Petak percobaan yang digunakan pada penelitian ini berukuran 4 × 3,2 m. Data dianalisis dengan sidik ragam dan perbedaan nilai tengah perlakuan ditentukan dengan uji BNJ pada taraf $5 \%$.

Variabel yang diamati meliputi bobot kering daun, batang, akar, malai, biji, indeks panen.Lahan diolah dengan pembajakan rotari dan garu sebanyak satu kali.Tanah yang telah diolah kemudian dibua t menjadi petak-petak lahan dengan ukuran 3,2 m x $4 \mathrm{~m}$ dan jarak antar digunakan pada penelitian ini ubikayu adalah $80 \mathrm{x}$ $60 \mathrm{~cm}$ dan tanaman sorgum ditanam disela tanaman ubikayu dengan jarak $80 \times 20 \mathrm{~cm}$. Pemupukan Urea, SP-36 dan $\mathrm{KCl}$ dengan dosis 200, 100, $100 \mathrm{~kg} \mathrm{ha}^{-1}$. Pemberian pupuk dilakukan sebanyak dua kali. Pemeliharaan pada penelitian ini adalah pengendalian gulma,dan pembuatan parit. Pengendalian gulma dilakukan secara manual menggunakan arit dan cangkul. Pembuatan paret dilakukan apabila curah hujan tinggi supaya tidak menggenang disekitar areal pertanaman.

\section{HASIL DAN PEMBAHASAN}

Tabel 1 menunjukan bahwa pola pertanaman berpengaruh nyata terhadap bobot kering daun pada 6 12 minggu setelah tanam (mst), batang 6-10 mst, akar pada 4-12 mst, malai dan biji sorgum $12 \mathrm{mst}$. Genotipe sorgum berpengaruh terhadap bobot kering daun, batang,akar. Sedangkan interaksi nyata pada bobot kering akar 4 mst dan 6 mst. Sebaliknya interaksi pada pola pertanaman dan genotipe tidak berpengaruh nyata pada variable pengamtan kecuali bobot kering akar pada 4 dan 6 mst.Hasil penelitian menunjukan bahwa akumulasi bahan kering tanaman sorgum pada batang, daun akar berbeda. Pada umur $4 \mathrm{mst}$, sorgum lebih banyak mengakumulasi bahan kering pada batang, diikuti oleh daun dan akar, distribusi bahan kering tanaman sorgum pada sistem monokultur mendapatkan akumulasi bahan kering yang lebih besar ddibandingkan dengan tumpangsari (Gambar 1). Seperti yang terjadi pada umur $4 \mathrm{mst}$, pola diatribusi bahan kering tanaman sorgum pada 6 mst juga menunjukan pola yang sama antara sorgum yang ditanam secara monokultur dan tumpangsari (Gambar 2).

Dalam hal ini, sebagian besar bahan kering diakumulasikan dibatang, daun dan akar. Pada Gambar 2 menunjukan bahwa pada umur 6 mst. Distribusi bahan kering sebagian besar terdapat pada batang, daun lalu akar. Pola distribusi bahan kering pada pola pertanaman monokultur lebih mendapatkan akumulasi bahan kering

Tabel 1. Pengaruh pola tanam dan genotipe sorgum terhadap bobot kering daun, batang, akar, malai, dan biji, dan indeks panen.

\begin{tabular}{|c|c|c|c|c|c|c|c|}
\hline Perlakuan & BKD & BKB & BKA & $\mathrm{BKM}$ & BKJ & \multicolumn{2}{|c|}{ IP } \\
\hline Pola Pertanaman & \multicolumn{7}{|c|}{ 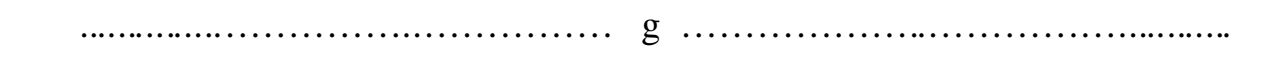 } \\
\hline Monokultur & $15,11 \mathrm{a}$ & $17,58 \mathrm{a}$ & $7,43 \mathrm{a}$ & $6,91 \mathrm{a}$ & $42,01 \mathrm{a}$ & 37,01 & \\
\hline Tumpang sari & $14,82 \mathrm{a}$ & $17,13 \mathrm{a}$ & $6,97 \mathrm{a}$ & $4,77 \mathrm{a}$ & $37,72 \mathrm{~b}$ & & 40,36 \\
\hline \multicolumn{8}{|l|}{ Genotipe : } \\
\hline Batan S-3 & $14,83 \mathrm{a}$ & $16,99 \mathrm{a}$ & $7,02 \mathrm{a}$ & $4,70 \mathrm{c}$ & $30,92 \mathrm{c}$ & 42,04 & 45,38 \\
\hline Batan S-12 & $15,45 \mathrm{a}$ & $16,95 \mathrm{a}$ & $6,97 \mathrm{a}$ & $4,55 \mathrm{c}$ & $29,92 \mathrm{c}$ & 42,94 & 45,46 \\
\hline Keller & $15,04 \mathrm{a}$ & $17,39 \mathrm{a}$ & $7,21 \mathrm{a}$ & $6,02 \mathrm{~b}$ & $46,05 \mathrm{ab}$ & 33,59 & 37,50 \\
\hline Wray & $15,22 \mathrm{a}$ & $17,55 \mathrm{a}$ & $7,38 \mathrm{a}$ & $6,15 b$ & $43,85 \mathrm{~b}$ & 33,92 & 38,44 \\
\hline Numbu & $14,28 \mathrm{a}$ & $17,90 \mathrm{a}$ & $7,42 \mathrm{a}$ & $7,80 \mathrm{a}$ & $48,85 \mathrm{a}$ & 32,59 & 35,02 \\
\hline
\end{tabular}

Keterangan: Angka yang diikuti huruf sama pada kolom dan perlakuan yang sama menunjukkan tidak berbeda nyata menurut uji $\mathrm{BNJ}$ pada $\alpha_{0,05}$. $\mathrm{BKD}=$ bobot kering daun, $\mathrm{BKB}=$ bobot kering batang, $\mathrm{BKA}=$ bobot kering akar, $\mathrm{BKM}=$ bobot kering malai, BKJ = bobot kering biji, dan IP = Indeks panen. 
lebih besar dari pada tumpangsari.Akumulasi bahan kering tanaman sorgum umur 8 mst, bahan kering sorgum lebih banyak mengakumulasikan bahan kering pada batang, daun, lalu akar. Pada umur 10 mst akumulasi bahan kering menunjukan pada pola pertanaman monokultur akumulasi bahan kering sorgum pada daun dan batang hampir sama sedangkan akar mendapatkan akumulasi terkecil lihat Gambar 3 sedangkan pada pola tumpangsari akumulasi bahan kering terbesar sebagian besar terdapat pada batang, daun lalu diikuti oleh akar. Hasil penelitian menunjukan bahwa akumulasi bahan kering pada umur 12 mst pada monokultur dan tumpangsari sebaran terbanyak pada batang lalu daun dan diikuti akar. Pada umur 12 mst akumulasi bahan kering pada daun terjadi penurunan dikarenakan

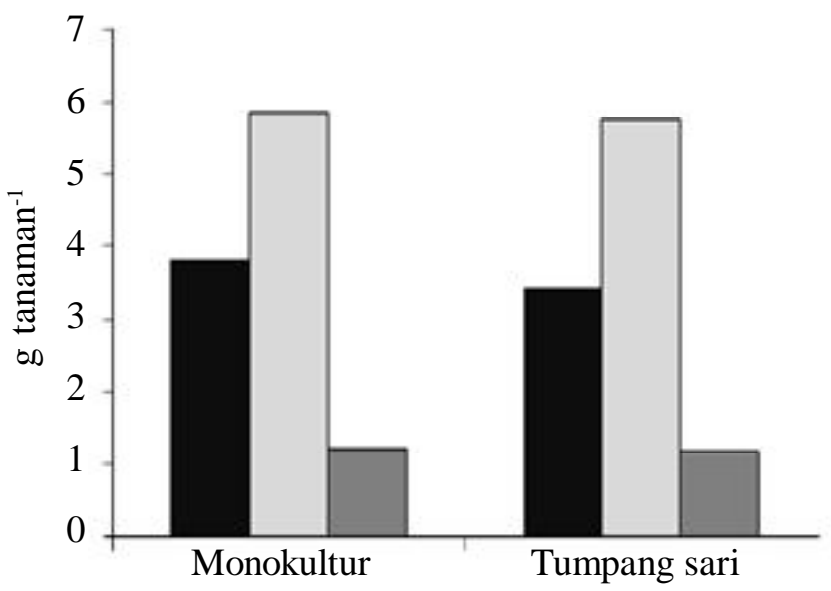

Pola Pertanaman

Gambar 1. Pola distribusi bahan kering tanaman sorgum umur 4 mst pada monokultur dan tumpangsari. $\square=$ daun, $\square=$ batang dan $\square=$ akar.

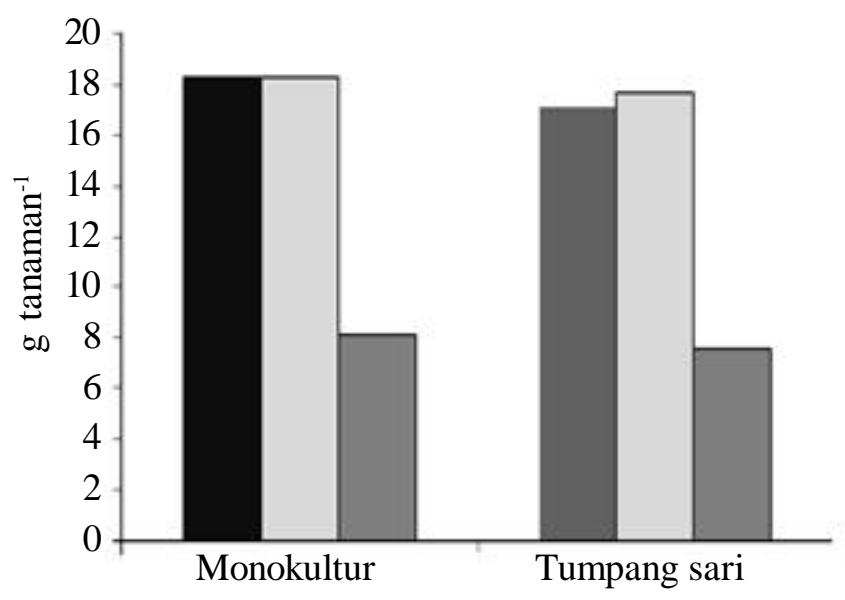

Pola Pertanaman

Gambar 3. Pola distribusi bahan kering tanaman sorgum umur 10 mst pada monokultur dan tumpangsari. $\square=$ daun, $\square$ = batang dan $\square=$ akar. akumulasi bahan kering dilanjutkan pada organ tanaman lainnya (Gambar 4).

Hasil dari proses distribusi bahan kering tanaman sorgum baik yang ditanaman pada sistem monokultur dan tumpangsari , fotosintat terbesar disebarkan pada organ tanaman berupa batang. Hasil fotosintat selanjutnya disebarkan ke organ tanaman sorgum berupa akar. Akar tanaman sorgum mempunyai bobot kering yang ukurannya relatif lebih kecil dibandingkan kedua organ tanaman sorgum lainnya. Hasil penelitian menunjukan bahwa indeks panen yang didapat pada monokultur dan tumpangsari. Menunjukan pola pertanaman tumpangsari mempunyai indeks panen yang lebih besar dari pada indeks panen yang ditanam secara monokultur, begitupun pada genotipe tanaman sorgum

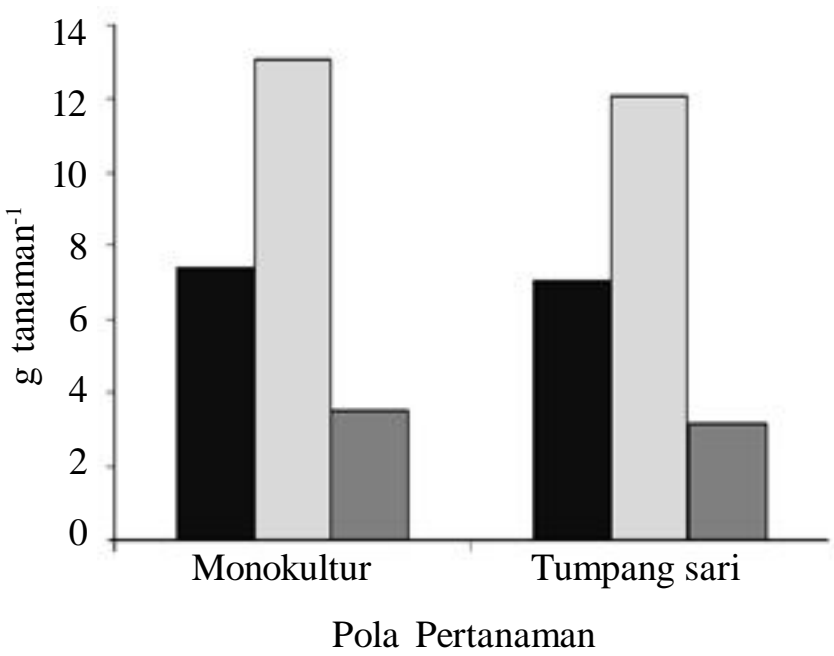

Gambar 2. Pola distribusi bahan kering tanaman sorgum umur 6 mst pada monokultur dan tumpangsari. $\square=$ daun, $\square$ = batang dan $\square=$ akar.

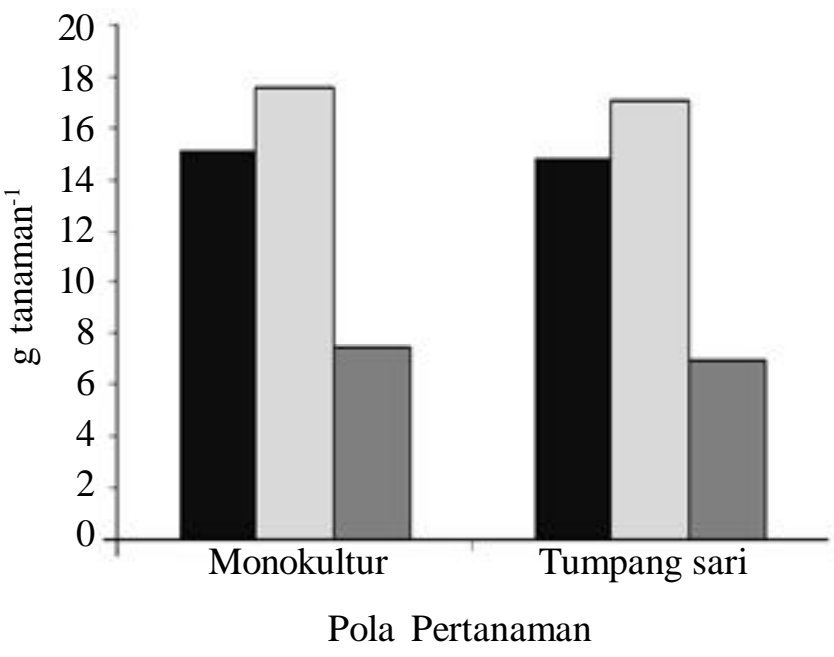

Gambar 4. Pola distribusi bahan kering tanaman sorgum umur 12 mst pada monokultur dan tumpangsari. $\square$ = daun, $\square$ = batang dan $\square=$ akar. 
yang ditanam secara tumpangsari mempunyai indeks panen yang lebih besar.

Akumulasi bahan kering tanaman sorgum pada batang, daun dan akar berbeda, secara umum akumulasi bahan kering tanaman sorgum sama pada monukultur dan tumpangsari. Sorgum lebih banyak mengakumulasikan bahan kering pada bagian tanaman terutama batang pada daun lalu yang terkecil didapat oleh akar. Walaupun dengan jumlah akumulasi berbeda pada monokultur dan tumpangsari. Kusumo (2012) melaporkan bahwa berangkasan kacang hijau dan kacang tanah pada umumnya mengandung porsi daun lebih rendah dan porsi batang lebih tinggi. Dengan demikian komposisi dari kedua tanaman tersebut tidak ada perbedaan. Pada monokultur akumulasi bahan kering pada organ tanaman pada batang, daun dan akar lebih banyak di bandingkan pada tumpangsari. Pada tumpangsari akumulasi bahan kering rendah dikarenakan ada pengaruh dari lingkungan. Salah satu adanya persaingan cahaya, yang berasal dari ubikayu, yang mengakibatkan menyebabkan proses fotosintesis terhambat. Sedangkan pada sistem monokultur persaingan yang terjadi sangat rendah karena hanya terjadi pada jenis tanaman yang sama, sehingga persaingan mampu dihindari.

\section{KESIMPULAN}

Kesimpulan dari penelitian ini adalah pola pertanaman monokultur dan tumpangsari berpengaruh pada bobot kering daun 6 - $12 \mathrm{mst}$, batang $6,10 \mathrm{mst}$, akar 4 - 12 mst. Pertanaman monokultur menghasilkan bobot kering daun, batang, dan akar lebih besar dari pada pertanaman tumpangsari. Sebagian besar bahan kering diakumulasikan pada batang diikuti daun dan yang terkecil pada akar.Perbedaan genotipe berpengaruh terhadap bobot kering daun pada 6 - 12 mst batang pada 4, 6 dan 10 mst dan akar pada 6 dan 8 mst.

\section{SANWACANA}

Ucapan terima kasih saya sampaikan kepada Prof. Dr. Ir. Muhammd Kamal M.Sc, Ir. Sunyoto M. Agr.,dan Dr. Ir. Agus Karyanto MSc. atas semua bantuanya selama melaksanakan penelitian.

\section{DAFTAR PUSTAKA}

Kusumo, H, B. 2012. Kualitas dan hay berangkasan sorgum yang dipergunakan sebagai pakan sapi jantan muda. Prosiding Insinas. Vol. 15(3): 2221.

Sirappa, M.P. 2003. Prospek pengembangan sorgum di Indonesia sebagai komoditas alternatif untuk pangan, pakan, dan industri. Jurnal Penelitian dan Pengembangan Pertanian, Jakarta 22 (4): 133-140.

Sitompul, R., dan Bambang Guritno.1995. Analisis Pertumbuhan Tanaman. Yogyakarta: Gadjah Mada University Press. 45 hlm.

Gardner, F. P., R. B. Pearce., R. Roger, dan I. Mitchel. 1985. Physiologi of Plant. Lowa State University Press. Dalam Tohari, S. 1992. Fisiologi Tanaman Budidaya Tropik. Gajah Mada University Press. Yogyakarta. $95 \mathrm{hlm}$.

Zanski, E. dan A.A. Schaffer. 1996. Photoassimilate Distribustion in Plants and Crops Source Sint Relationships. Marcel Dekker Inc. New York. $98 \mathrm{hlm}$. 